\title{
Postcolonial Stakes of Congolese (DRC) Political Space: 50 Years after Independence ${ }^{1}$
}

\author{
Sarah Demart ${ }^{\mathrm{a}}$ and Leïla Bodeux ${ }^{\mathrm{b}}$ \\ a) F.R.S.-FNRS research fellow, Center for Ethnic and Migration Studies (CEDEM) \\ University of Liège, Belgium \\ sarah.demart@ulg.ac.be \\ b) MSc in African Studies, University of Oxford, 2010-2011, UK \\ leilabodeux@hotmail.com
}

\begin{abstract}
This joint contribution interrogates the postcolonial relations that are at play in the Congolese political sphere in Belgium, the former colonial metropolis. Two lines of argument are developed. First, the politicisation of the postcolonial relations, which pre-dates the Congolese immigration to Belgium, is viewed from a historical perspective. Second, the highly competitive political pluralism, as observed since the early 200os, is examined. After having restored historically the constitution and the reconstruction of this political sphere, wherein new technologies deepen the transnational movements, the authors will examine the tensions that arise from the unifying dynamics of the politically engaged Diaspora, on the one hand, and its intrinsic logics of division and fragmentation, on the other. The postcolonial issues that are at stake are to be seen on different levels: transnational, local, within the Diaspora, and between the Congolese minority and the Belgian majority. Their interconnectedness further reveals the postcolonial character of this political sphere.
\end{abstract}

\section{Keywords}

Congolese Diaspora, political involvement, Belgium, postcolonial relations

\section{Résumé}

Dans le cadre de cette contribution à deux voix, nous interrogeons les enjeux postcoloniaux du champ politique congolais en Belgique, l'ancienne métropole. Deux grands axes sont développés. Premièrement, la mise en perspective historique de cette politisation, avant même l'existence d'une immigration congolaise en Belgique. Deuxièmement, le pluralisme politique, hautement concurrentiel qui se donne à voir depuis le début des années 2000. Après avoir restitué la constitution et la recomposition, dans le temps, de ce champ politique, dont le transnationalisme,

1) We would like to extend our thanks to Jean-Michel Lafleur and Didier Gondola for their critical reviews of this work and to the journal's anonymous reviewers for the care and precision of their remarks. 
immédiat, est amplifié par l'arrivée des nouvelles technologies, nous examinons la tension entre d'une part, les dynamiques fédératrices du champ, et d'autre part, les logiques de division et de fragmentation qui travaillent ces collectifs. L'enjeu postocolonial se donne alors à voir à différents niveaux - transnational, local, au sein même de la diaspora et entre la minorité congolaise et la majorité belge - dont l'imbrication même traduit la postcolonialité de ce champ politique.

Mots-clés

diaspora congolaise, engagement politique, Belgique, enjeux postcoloniaux

\section{Introduction}

In December 2011, while some parts of the Congolese ${ }^{2}$ diaspora demonstrated across five continents in order to denounce the irregularities in the 2011 presidential elections, very violent clashes between demonstrators and police forces broke out in Belgium. For two weeks, spontaneous demonstrations took place, which sometimes were tolerated and sometimes prohibited. The daily toll included dozens of demonstrators arrested, smashed shop windows and cars and trash bins set on fire. In the 'African' neighborhood of Matonge (Brussels) violence erupted systematically every night. Day after day, demonstrators were pushed back in the area, sometimes after hours of clashes with the police. Ironically, both demonstrators and policemen seemed to have forgotten that Matonge originated during the 1970s in the former colonial landscape (Demart 2013a) before the Congolese- settlement in Belgium at the end of the 1980s, although Congolese started to come in Belgium from 196o (Etambala 1993; Mayoyo 1995). This history of place and its reconversion gave the conflict, which the media was quick to portray as riots, a significant historical dimension. Nevertheless, it is not at that level that the postcolonial rhetoric appeared. It was the demonstrators' discourse that saw police repression as evidence of the support Belgium provided and continues to provide to the power-holders in Kinshasa. It is true that such a display of police force was rarely seen in Belgium, as it included local and federal police, heavily armed and sometimes in civilian clothes, using horses, dogs, and helicopters. The Belgian state was determined to stop what appeared to several observers as a transposition of Congolese political conflicts into its territory. ${ }^{3}$ After two weeks of conflict, the minister of home affairs Joëlle Milquet, whose party had been actively looking

2) From the Democratic Republic of Congo (DRC).

3) See the different press releases of the Commune of Ixelles where clashes systematically broke out. 
for the Congolese vote (Wynants 2010; Demart 2013b), finally spoke out against the demonstrations only to refute any lax attitude of the state. It seemed as if the police repression compensated for the political silence.

The demonstrations were initiated by a pressure group from the diaspora, the so-called Combatants (Fighters), known for their violent opposition to Kabila's regime in Kinshasa, yet lacking a support base within the Congolese diaspora. However, during this electoral period, they were joined by supporters of Etienne Tshisekedi (the candidate for the main opposition party). When the conflict grew, apolitical young people born in Europe and "mamas"4 joined the protests claiming sovereignty for their country of origin, regardless of who won the presidential election (Demart 2013c). Later on, when demonstrations were authorized in Antwerp and Brussels, public figures such as prominent members from the diaspora (community, religious or artistic people) joined the demonstrators. While remaining anonymous, they expressed their wish to see demonstrations end up with concrete demands linked to the situation of the Congolese in Belgium. But after ten days of clashes, these public figures distanced themselves from the movement. After having physically pushed back journalists, the Combatants called for a boycott of the French-speaking political parties (Demart op. cit.). Congolese, according to the Combatants, should vote in the 2014 Belgian elections for Flemish parties, ${ }^{5}$ known for being less conciliatory with Kabila's power. In a context in which postcolonial dispute is placed at the margin of society, despite the huge conflicts never seen before, these public expressions can be closer examined and contextualized in regards to the Congolese presence and politicization in Belgium since the 1960 .

Political transnationalism of diasporas has rarely been investigated through a postcolonial lens (Mügge 2010; Turner 2008), a term often reduced to a chronology of events while postcolonial studies have richly explored the multibelonging of (black) diasporas. However, transnational activities can come from local and diasporic interests that relate to colonial history or to postcolonial relations in a (post)migratory situation.

By putting into perspective the historicity of political transnationalism, postcolonial stakes come to light. Indeed, looking at the Congolese presence, one can see that its political and social transformation in the former metro-

\footnotetext{
4) "Mama" in Congolese culture is used for women (little girl, teenager, married women, widow, etc.) in general, but here during the protestations, the women are not young and not necessarily politically active.

5) Belgian political context is very complex and is characterized by increasing tension between the French speaking and the Flemish speaking political parties.
} 
pole is since independence related to the connection Kinshasa - Brussels. Congolese presence in Belgium simultaneously redefines the Congolese political landscape.

People's spatial mobility is closely associated with their displacement in the political space. Their transnationality is immediate and, like African politics, largely depends on institutional mechanisms inherited from colonization (Bayart 1993). Our focus of attention concerns the postcolonial dimension of the political activism of the Congolese diaspora which also led us to look at the postcolonial critique which is very present in the activists' demands and triggers huge divisions among them. We will also consider the local and transnational features of the organization of this political field.

Our paper will be divided into four parts. Firstly, we will discuss the link between transnationalism and postcolonialism from the literature point of view and consider a particular case in order to grasp (post)colonial features. Secondly, we will trace the political history of the Congolese presence in Belgium since independence and the progressive constitution of a diverse political Congolese diasporic scene in the aftermath of migratory flows and of political regime changes in the DRC, ex-Zaïre (1971-1997). Thirdly, we will put in perspective the internal dynamics of this political space in examining the different structures and the heterogeneity of the opposition in order to highlight the main elements of these political diasporic divisions. Finally, we will investigate the discourses of protest that transcend diasporic and political divisions in terms of mobilization. We will also tackle the diaspora's impact on the so called Congo's experts within Belgium.

Regarding empirical material, we have collected data in French-speaking Belgium in the politically active Congolese diaspora community (political parties, blogs, associations, pressure groups, religious groups, journalists, demonstrations etc.) mainly in Brussels between 2005 and 2011, but also in Leuven and Antwerp during the demonstrations in the winter of 2011-2012. Most of our empirical material consists of formal and informal interviews (political movements and party leaders, members, demonstrators, supporters, the "elders," etc.), of an analysis of websites (diaspora press from Belgium and elsewhere, ${ }^{6}$ and Congolese national ones, ${ }^{7}$ because of their wide audience and their

\footnotetext{
6) Mainly "Banamikili" (Children from Europe), "Debout Congolais" (stand up Congolese, the DRC national anthem title), "Nkolo Mboka" (authentic child of the country), "CongoMikili" (Europe's Congo), “Cheik Fita news," “Congo Indépendant”.

7) Mainly "Digital Congo", "Le phare”, "Le Potenciel”, "Jeune Afrique”, "le Soft", "La Prospérité”, "Africatime".
} 
popularity within the diaspora), and the analysis of social networks (from 2005 to 2012, and more intensively during both presidential elections in 2006 and 2012). Belgian journalists have also been interviewed in 2011.

However, our purpose is not a mere description of this ethnographic material (observations, interviews) but a reflection based on fragments of this empirical material in order to bring out on the postcolonial stakes at work within the Congolese political field in Belgium.

\section{Transnationalism and (Post)Colonial Features}

The demonstrations of the winter of 2012 have shown that transnational spaces relate not only to collective and transnational mobilization but also to colonial hallmarks especially if we consider the way a diaspora can create a particular form of a "liberation fight." The idea to put pressure on the host country, also a member of the "international community", to "free" Congo significantly relates to the "status" of the home country as a former "international colony". This status takes root in the way Congolese territory was given to the king of Belgium at the end of the nineteenth century (enshrined in the Berlin Conference). This territory was a free economic zone allowing free movement of capital during Léopold II's regime (1885-1908) (Ndaywel 1998; Hunt 2008). Although this configuration took end with the Belgian colonization, political events appear to the diaspora strongly related to this configuration such as the Katanga's secession in the early 1960 s (de Witte 2000) or the "neoliberalism" underlying the impunity in which the war is going on in Eastern DRC since 1998. Among the diaspora indeed, the idea of "an international conspiracy" against DRC is widely spread. In this respect, the demonstrators have denounced the involvement of foreign companies and Western states in the "Rwandan war" against DRC, adding their voice in the "Conflict Minerals" issue.

Along with the "international colony" theme two other themes figure prominently: the "unique colony," private property of King Léopold II (1885-1908) and the "huge colony" (1908-1960) belonging to small Belgium although the configurations are at some point quite interchangeable. Demonstrators believe the DRC to be still treated as a kind of trust territory through the "expert" position that Belgium is supposed to have on the international scene. Belgium's responsibility in the war is singled out because of the role Belgium played in manipulating and hierarchizing ethnicities (Tutsis vs. Hutus, Nilotics vs. Bantus) and in displacing populations within its territory during the colonial period 
(by organizing the migration of Rwandan population to Congo ${ }^{8}$ that was primarily a colony of exploitation).

Secondly, even if the politicization of Congolese in Belgium dates back to the 1960 s, ${ }^{9}$ we argue that this "politics from below" (Bayart, Mbembe and Toulabor 1992) took on a different scope with the arrival of social medias (Martiniello and Lafleur 2008; Vertovec 2004). These have facilitated relations with the country of origin and have allowed a "double involvement" of the host and origin country (Grillo and Mazzucato 2007). New technologies have also increased the visibility of the actors in a public space that redefines the political borders of the origin country. These dynamics are present in transnationalism studies that boomed in the 1990s and tend to blur concepts (Kivisto 2001). We take as a reference Basch et al.'s (1994: 7) definition of transnationalism: "processes by which immigrants forge and sustain multi-stranded social relations that link together their societies of origin and settlement". As we will see, the diversity of the profiles we interviewed and the political actions we observed lead us to contend that the categories of analysis must be broadened. These should include a wider variety of statuses (refugees, migrants, minorities), direct and indirect channels of participation (Østergaard-Nielsen 2003: 762), as well as activities and networks that are not reduced to initiatives from the government of the country of origin (Martiniello and Lafleur 2008).

Although not exclusive to transnationalism, diaspora as a "social form" and a "type of conscience" (Vertovec 1999) corresponds with phenomena we have observed such as exile, dispersion, long-term residency in a foreign country, the desire of return, and the sometimes idealized and mythical vision of the origin country. The auto-identification as being a member of the diaspora can exist alongside forms of more or less transitory return. The actors we interviewed belong globally to the first generation of migrants and are in the majority men. Nevertheless, different migration waves have been identified, each wave corresponding to a different socio-educational level related to the home country's socio-economic situation.

The patterns of spatial and social mobility that prevailed in the 1960 s and 1990s have changed (e.g. obtaining a degree in Belgium to attain an important position in DRC). But because of the difficult integration in the host country (Guarnizo, Portes and Haller 2003), the country of origin continues to be

\footnotetext{
8) Belgium "inherited" a trusteeship over Rwanda and Burundi after World War One.

9) The politicization of Congolese in Belgium started before 1960 if we consider the "Association des Congolais de Belgique" and Paul Panda Farnana's trajectorie (Tshitungu, 2011), the first intellectual and panafricanist Congolese (1888-1930).
} 
perceived by elders as allowing for social integration and prestige. The lack of integration and high unemployment figures among the Congolese in Belgium are well-known despite their high levels of education (Schoonvaere 2010) and the fact there are more and more lawyers or consultants (engineers) of Congolese origin.

It is therefore not surprising that in the diasporic geography, the Congolese of Belgium (i.e. bana lola (children from Paradise in Lingala) are not only seen as elite (because of their historical background) but as "having the time". In other words there is a perceived link between the rate of unemployment and the numerous community and political associations in which they are involved.

"Theoretically" Congolese diaspora is situated in the case of the "nonelectoral political participation" (Bauböck 2003), due to the absence of electoral facilities abroad and the non-existence of the right to dual citizenship. The diaspora is nevertheless actively involved in Congolese legislative and provincial elections, which leads to significant dynamics of return that transform the juridical-national borders. The 2004 Congolese parliamentary debates illustrated the fact that around one-third of the Congolese National Assembly had a foreign nationality (from Europe, North America, and South Africa), a figure that seems to have declined since 2006 and the 2012 legislative elections.

In this context, we investigate the elements that allow us to explore logics, dynamics, or relations that can be qualified as postcolonial in the space of political transnationalism or as "imperial ruins" or "debris" (Hunt 1999; Stoler 2008). While in Africa postcolonial dynamics related to the formation of the state, the city, the religious, political or popular imaginary of inhabitants, or identities have been underlined by social sciences for decades, the study of colonial inheritance within former European metropole (state, autochthons imaginary specially) is significantly marginal (Cooper and Stoler 1997; Gilroy 2005; Lebovics 2004). It is as if, particularly in the French-speaking space, postcolonialism was eventually associated with a temporal and territorial elsewhere, and therefore with colonies, despite highly relevant works done on the French case (Bancel and al. 2003; Tshimanga 2004; Gueye 2011). In this regard, we absolutely need in the Belgian case to underscore the gap between the European and African space.

Without dwelling on the recent French dispute about the "good way to import postcolonial studies" (see introduction in this issue) it is important to underline that beyond the resistances and the conflicts of discipline, important questions surrounding the methods have been raised (Bayart 2010). In this paper, we have chosen a comprehensive sociology (Schütz 1987) approach 
that privileges the perspective of actors in order to restitute subaltern's view (Chakrabarty 2000; Saïd 1978) as well as internal strives, that are both constitutive of the diasporic political field. In this regard, claims' content and divisions' causes are the very hallmarks of the colonial legacy.

In other words, investigating forms of political involvement (local or transnational) through a postcolonial lens allows us to take into consideration the narratives of the actors, the historicity of their demands and what divides the political actors. These internal dynamics could be qualified as delocalized postcolony (Mbembe 200o) in the sense of that the definition of the present is fundamentally contentious precisely because of its colonial component (huge controversial around history, link between conflicts of memory and political ideology, political culture inherited of the (post)colonial state, etc.).

\section{History of Congolese Political Movements in Belgium}

The five years after Congolese independence (June 3oth 1960) have challenged the country's conditions for access to sovereignty. The involvement of Belgium and the "international community" in the brutal elimination of Prime Minister Patrice Emery Lumumba (January 17th 1961) - and in the secession of Katanga - have been largely documented (de Witte ibid.) and fuels the idea of an international conspiracy and the Congolese "martyrology" (Omasomba Tshonda 2004). The idea of a conspiracy was reinforced through a sequence of political events: the Mulelist rebellions, ${ }^{10}$ the installation of Joseph-Désiré Mobutu (1965-97) by Western powers, and most recently, the UgandanRwandese aggression in Eastern Congo, triggered with Laurent-Désiré Kabila's seizure of power in 1997 .

Since the 196os, Congolese lumumbists (supporters and allies of Patrice Lumumba like Antoine Gizenga, Laurent-Désiré Kabila, Abdulaye Yerodia Ndombasi, etc.) have sought political exile in communist and socialist countries (Cuba, Russia, Romania, RDA, Tanzania, Sudan, Egypt, Guinea Conakry, etc.). A few persona non grata in Belgium found refuge through exile in France and Switzerland. It is only since 1965 that political opponents with different backgrounds have been identified in the former metropole aside from diplomats, financiers, students, Congolese civil servants, and tourists.

10) Pierre Mulele was the Minister of education in Lumumba's government. With the assassination of Lumumba (1961) he entered upon rebellion until 1968, year of his assassination by Mobutu's troops (he was publicly tortured and executed). 
Some fled Congo after Mobutu's coup d'état while others went into exile because of individual conflicts with the president. The latter often went back and forth between Brussels (when they are in the opposition) and Kinshasa (when they return to power), for example, Monguya, former provincial governor, guz a Karl-I-Bond, former foreign minister and Head of the MPR Political Office or Mungul Diaka, several times a minister and ambassador. The denunciation of the regime from Brussels (sometimes in written form) took place in a context of regular conflict between Mobutu and the Belgian state. The political protest movements abroad became institutionalized after the creation of the MPR (Popular Movement of the Revolution) as a unique party in 1971. The students were undoubtedly the most committed protestors. Some of them refused to integrate into the J-MPR (Youth of the unique party, MPR), and instead they took part in the creation of the MARC (revolutionary movement of action for Congo) in 1976-1977. This movement enjoyed a certain aura in the Belgian media and political spheres in a period when students were chased by Zairian intelligence services (directed by Honoré Ngbanda, cf. infra) ${ }^{11}$ linked to the embassy (end of the 1970s to early 1980). This movement led Mobutu to accuse the Belgian government of "recruiting" Congolese students in order to create opponents to its regime (during a Meeting in Kinshasa, 1977-78 according to our informants). Nevertheless, when the MARC lost its president (killed in his mistress's house), Pierre Kanyonga in 1978 militants did not understand why Belgian police did not investigate the case. They interpreted this passivity as evidence of the ambiguities and complicities between the Belgium state and the Zairian dictatorship. Yet, it is worth underlining that the strong student mobilization and the regular organization of demonstrations against Mobutu did not provoke clashes with police and took place, as transnational mobilization, at a time when the Internet did not exist and international telephone calls were excessively expensive.

Then, the UDPS (Union for Democracy and Social Progress) started on February 16th 1982 in Zaïre) and was informally present in Belgium since 1985 . Laurent-Désiré Kabila's party, the PPR (Party of Popular Revolution), which was created in the bush (Eastern Congo) after Mobutu's take-over, was represented from 1983 by Kabila's cousin, Gaëtan Kakudji (Kennes and N'Ge 2003).

But it is mainly the fall of the Berlin Wall in 1989 that transformed the political landscape. Zaïre lost its Western support and facing growing local contestations, it was compelled to open up democratically. On April 24th 1990, the return to a multiparty system was officially announced. In the following

11) Zairian defense minister and former special Mobutu's advisor in charge of special services. 
months, almost 400 parties were created (around 300 were allowed) and a few of them were immediately represented in Belgium, ${ }^{12}$ France, and Germany. The Congolese diaspora in several countries (Europe, Africa, and North America) was significantly represented during the Sovereign National Conference (CNS, 1991-92) that extended the process of democratization.

It is not until the seizure of power by Laurent-Désiré Kabila on May 17th 1997 that an important return movement to Congo happened. Several Congolese from the diaspora received political functions, notably Gaëtan Kakudji who became Katanga's governor and then interior minister. Some practices similar to mobutism (illegal enrichment, arrogant behavior, etc.) stigmatized the members of this diaspora and more generally the diaspora as such, which was nicknamed "diaspourrie” (rotten diaspora). Moreover, since May 26th 1997, the new power suspended "temporarily" political parties' activities, prohibited any demonstration, and refused to implement CNS resolutions. The opposition, qualified as "multi-mobutism" by Kabila, had not been integrated into the power sharing and started to denounce the then "new dictatorship". ${ }^{13}$ Most of the "mobutists" went into exile in Europe. Often, their goods and belongings were confiscated or occupied, or they were forced to abandon them. In the 200os, many of them came back to DRC.

During this long exile, some of them created new political parties ${ }^{14}$ (De Villers and Willame 1999). This "moderate" opposition was hardly visible in the public space, in contrast to the UDPS (the historic opposition party run by Etienne Tshisekedi $)^{15}$ that openly denounced the diaspora "Kabila dictatorship" in DRC and within the diaspora When L.-D. Kabila was assassinated on January 16th 2001, the UDPS celebrated in Kinshasa and Brussels while other political activists collapsed, "The Western world hated him... All your countries have diabolized him because he said that Congo was a sovereign country and that it didn't need them... He achieved great things until Rwanda and Uganda invaded us with your countries... This day, I cried" (interview 15/06/2010, with

12) For instance the UDPS (see supra), the PDSC (the social catholic democrat party), the UFERI (the union of federalists and independent republicans), the UDI (the union of independent democrats), the historical lumumbist party, the MNC (the Congolese national movement), the UDECO (the union for Congo's development), the FONUS (New forces for union and solidarity), and of course the party-state, the MPR (the popular movement of revolution).

13) Many arrests occurred within the opposition and the leader of the UDPS retreated to his village of origin (in February 1998).

14) The "Union for the Republic" (also in Paris), the "the Gathering of Congolese patriots".

15) For so many years people believed he was the founder. However, Tshisekedi joined the founders a few months after the clandestine creation of this party. 
a journalist and former opponent to Mobutu, living in Belgium for more than 15 years).

The long transition period (2001-2006) that then began was marked by the (military) installation of Kabila's son as a transitional president by people close to his father, in a troubled and insecure context in which three-quarters of the country was occupied by Rwandese and Ugandan armies. International organizations called upon Congolese institutions to organize an "inter-Congolese dialog" that took place in Sun City, South Africa (from February 25th 2002 until December 17th 2003). This dialog resulted in a transitional government made up of one president and four vice-presidents from unarmed and armed opposition groups, aiming to lead the country towards presidential elections in 2005 . These finally took place in 2006 when the registration of the population was completed. An important diaspora delegation made up of political parties and civil society (NGOs and associations) came to Congo. Some of them merged with governmental bodies, sometimes "forgetting" the collective strife led by the diaspora and privileging individual ascension.

Finally, the week following Joseph Kabila's installation in power, the mobutist Honoré Ngbanda, in exile in Paris and building a new identity since he became Christian born again ${ }^{16}$ denounced (in an Afro-French newspaper) ${ }^{17}$ the supposedly Rwandese nationality of the new president, by contesting his biological affiliation with Laurent-Désiré Kabila. Joseph Kabila was at this time, a stranger to the "Kinois" since he grew up in Tanzania, even though LD Kabila clearly introduced him as his own son. Besides, he did not speak either Lingala or French when he arrived in Kinshasa.

The opposition, especially within the diaspora, spread these criticisms and accusations and even accused the president of being involved in the assassination of his own father. Besides federating a dispersed opposition, this accusation would structure the whole political debate for at least the next ten years. In 2006 and 2011, candidates running for the presidential election (Jean-Pierre Bemba then Etienne Tshisekedi), claimed the legitimacy of the autochthony, mwana mboka (the country's children) as opposed to mopaya (foreigners). Although the opposition is gathered around the slogan "Kabila out" ("Kabila degage"), "go back to Rwanda" ("zonga na Rwanda"), the political

\footnotetext{
16) When the country "democratized" in the 1990 and was confronted by fierce popular criticism, many regime leaders started to visit revival churches to testify to the occult practices of the mobutism regime. They made "repentance" and asked for forgiveness, while becoming born again.

17) Cf. interview in Jeune Afrique Economie, $\mathrm{n}^{\circ} 323$, January 15 th to February 4 th 2001.
} 
space remains extremely fragmented and characterized by shifting allegiances that are constantly redefined.

\section{Diaspora's Political Pluralism}

Congo's re-opening to multipartyism a few months after Joseph Kabila's ascension to power (November 17th 2001) bolstered highly competitive dynamics within the diaspora that were expressed institutionally and in the media. The politically-active diaspora is made up of a dozen representatives of the main political parties in Belgium, ${ }^{18}$ political-community movements, and pressure groups that emerged in the early 2000s. These pressure groups that target the political power in Kinshasa are Bana Congo (Congo's children), Bamama Totelema (Mamas let us stand up), Mirgec (Independent movement for the recognition of the Congolese genocide) and of course the Combatants. The party of Honoré Ngbanda founded in 2005 in Paris, the APARECO (Alliance of patriots for the refoundation of Congo) may fit this category.

There are also associations like "Tshisekedi for President" that raise funds to finance UDPS political campaigns or human rights organizations like "the electors' league" (supported by the International Federation for Human Rights), "Aprodec" (Association for the promotion of democracy and development in DRC), or the think tank Epiphanie created by Catholic priests that defend open-minded positions within the public space and the Church against power in Kinshasa. Bloggers and "journalists" (by education or auto-proclaimed) are the ones that transmit or film the diaspora's activities while following on a daily basis political events in DRC, although most of these organizations have websites.

The only organizations that defend Kabila's power aside from the presidential party, quite discreet in the diaspora, are the group "Stand up Congolese" ("Debout Congolais"), which is not very active today, and the "reflection and action group on Congolese issues" INTAL-Belgium, an "international solidarity movement", close to the Marxist party PTB (Belgian Workers Party) that has never hidden its unconditional support of LD Kabila.

18) PPRD (People's party for reconstruction and democracy), PALU (Unified Lumumbist party), and for the opposition, the MLC (Congo's liberation movement), UDPS (Union for democracy and social progress), UREC (Union for Congo's reconstruction), ECIDE (Involvement for citizenship and development), UNC (Union for the Congolese nation), MNC (the national Congolese movement), or ANADER (National democrat alliance for reconstruction). 
Generally speaking, political activities comprise conferences, memoranda, or debates emanating from associations, churches, or academics, more or less militant. These activities can have an advocacy objective or a goal of electoral support. Conferences organized by Belgian political institutions or universities represent moments of expression and contestation when the established expertise is the target of virulent contestation by the "Congolese" audience. Other movements or associations could be considered such as Firefec (Forum Inter Regional des Femmes Congolaises pour le Développement International asbl) or le Collectif des Femmes pour la Paix et la Justice (The Women's collective for Peace and Justice $)^{19}$ even though the political dimension of their struggle is not linked to any political institution or ideology.

Nevertheless, it is certainly on the Web that the debate, the production, and circulation of information are the most intense, precisely because for all these actors the war is above all an "information warfare." In this regard divisions are collectively seen as "the problem of Congolese people" - partly inherited from colonization - and fed by Western media. Whatever their political opinions, nationalism and patriotism will be emphasized.

Concisely, we can say that two confrontational political analyses of the DRC crisis coexist;

- On the one hand, one view focuses on Joseph Kabila, described as a foreigner, a bloody dictator, and complicit in the Rwandan aggression war. Kabila is considered as a Trojan horse and a pawn of the West. He embodies a powerful state and is held responsible for all the crimes perpetrated on DRC territory.

- On the other hand, some people recognize Kabila's efforts to rebuild the country, through, for instance, "Chinese contracts" in a political context marred by war, failed institutions, the absence of a real army, the permeability of borders and pressure from the international community against Congolese interests. Some people praise his will to break up with French-African or Belgian-Zairian cultures in refusing, for example, to open a bank account or buy villas in Europe. For his more or less radical supporters, his political weaknesses lies within his communication, the authority he has over his close circle the ethnic-regional monopolization (Swahili-speaking), and the significant presence of former mobutists in institutions. Both sides share the assessment over the permanence of mobutist culture in the political and institutional space.

19) See the contribution in this issue of Godin, Grégoire and Bolya. 
Between these two visions, a wide variety of interpretation exists, leading us to think that the political repertory's ideological fractures are not so much about different opinions as they are about contradictory understandings of events, largely dependent upon different memories and sometimes an opposition between history and imaginary, if not an interweaving. It may seem paradoxical (Hirschmann 1970) that the accusations against the Kinshasa regime have reached a peak while the power is described as dictatorial and omnipotent.

New technologies facilitate this long distance freedom of speech (Bernal 2006), in contrast to the insecurity of opponents that dominated in Brussels in the 1970s and 1990s. In the era of globalization, the diaspora eventually appears as a space extremely secure for opponents and risky for people close (or supposedly close) to Kinshasa's power. The "Combatants", a movement born in the UK at the early 2000s (Garbin and Godin 2013) before spreading quickly to the rest of the diaspora, is the explanation. This small group of activists characterized by a military rhetoric and often dressed in combat uniform, express the necessity to take up arms to free the country. One of the hallmarks of the Combatants' organization is cross-border mobility and by extension, the investment in public space. Demonstrations are organized in Holland, Germany, France, and, less frequently, in the UK (where visa requests have been refused several times). For several years, the Combatants have refused musicians and pastors access to the space of the diaspora by accusing them of corruption and of distracting the masses. Several internationally-known singers therefore do not perform in Brussels or in the West anymore. On April gth 2011, Papa Wemba asked the President of the National Assembly to provide security to Congolese artists while touring abroad. ${ }^{20}$ In February 2012, the former information minister Lambert Mende questioned French authorities repeatedly about attacks that were carried out by French citizens (of Congolese origin) on Congolese citizens traveling in Europe (VOC- Lambert Mende sur l'agression de Kengo [interview DigitalTv], 1 January 2012, http://www.youtube.com/ watch?v=BQEdONuSWqc). We can cite two examples: She Okitundu, former director of J. Kabila cabinet, who was attacked in London in October 2006 and Léon Kengo, President of the Congolese Senate, who was mugged in Paris on January $5^{\text {th }}$ 2012. These activities are filmed and available on websites (Congomikili, Banamikili, Cheick Fita News, etc.), blogs, and social networks.

During the manifestations of November-December 2011, the term "Combatant" has taken a broader meaning and is used to designate militant action against Kinshasa's power. However the Combatants are frequently referred

20) Congo Independant, 11/04/11. 
by diaspora to as "thugs" because of their methods and their low level of education.

They indeed contrast with political parties' representatives that are generally older (between 40 and 50 years old), hold a university degree, and have a high social capital. Combatants often migrated in the 1990 and 2000 s to flee the war in Eastern Congo. They were socialized in institutions struck by the socio-economic collapse of Mobutu's Zaire. But for one Combatant, whom we met in Matonge during a "gathering ban" close of the curfew (December 2011), their methods are not the problem: "Ok, our methods are contested, but many Congolese are politically involved in our cause and authorities continue to ignore their demands". This feeling is shared beyond this pressure group and can lead some people to accept their actions, like this party's representative: "These activities defend the Congolese cause. They are noisy but say the same thing as us. I agree with them and support them even if we have had divergences" (co-founder and representative of the party Ecidé, 30/03/2011). Nevertheless, these differences of practices and strategies often lead to "rupture". When we asked a leader of Bana Congo about collaborating with Aprodec, he answered: "No, they make us sleep. We are fed up with conferences. In our opinion, it's action first: we act and we explain later!" (co-founder of the Bana Congo, 6/04/2011).

For some organizations, it is frustrating to notice that the "Combatants" are the ones that attract media attention - even before the demonstrations. In this regard, the Combatants' manichean rhetoric is noted in the ways in which it often morally disqualifies those who prefer attacking the presidential power on its political work rather than on the allegedly foreign origin of the President. Often this is reinforced by narratives in which the personality and integrity of leaders of the opposition in the diaspora are questioned or their motifs and loyalties become a subject of critique.

Behind the occupation of the political space by political entrepreneurs, there are different ways of "fighting" and of significant alliances of circumstance within the opposition. Apart from the old militants of the UDPS, the entry of actors into the opposition (or into politics) seems to date back to the times of the DRC transition. In this respect we must emphasize that it is not always easy to identify the motivations, or to know to what extent exclusion or the failure to participate in Kinshasa political-economic space is an incentive to begin a political fight. The Transition was also an intense moment of promotion opportunities for the diaspora in regards to the redistribution of positions (within the government, the public firms, etc.) that occurred.

More or less lasting alliances between parties and movements question the frontiers of the opposition that defines itself as "radical". The representative of 
a lumumbists party that was few years/months later within the presidential majority has, for example, been in opposition, even though he never agreed to participate in the actions carried out by the Combatants. On the other hand, the Combatants that organize anti-Kabila demonstrations with the UDPS are not always convinced of the party's legitimacy. Even if they have marched for years alongside the party of Honoré Ngbanda, they do not hesitate today to diabolize him, reminding him of his mobutist past. Without analyzing the political-religious features of this discourse (Demart, 2010) and its mobutist legacy, we would like to underline the extreme scrambling of political identities that these methods of disqualification generate. The Combatants movement definitely exacerbates this logic of suspicion.

Transnational diasporic debates permanently highlight the question of the "traitor" and the patriot. It is not only Joseph Kabila that divided people, but also the history of the country and of its leadership in general. For example, the representations of Etienne Tshisekedi generate two versions of Congolese history. One version represents him as a historical figure of the opposition who sacrificed his life for the fight for democracy. The other version portrays him as complicit with mobutist power because of his implications in several political episodes regarding his landholdings. The same can be said of Jean-Pierre Bemba, candidate for the second round of 2006 presidential elections, and of a number of political figures. In other words, internal divisions are perceived as responsible for the failure of the country to become stable and prosperous, despite its incalculable wealth. Beyond the issues of memory (Bancel and Riot 2009) this relates to the different ways of analyzing the international politics, particularly in the evaluation of the State's room for maneuver that the international bodies "allow" to the Congolese power.

\section{Beyond Divisions...}

Social division emanating from internal differentiations within the diaspora and from the dynamics within the Congolese political space are clear-cut. Nevertheless, we can identify recurrent and crosscutting themes where the political involvement is systematically outlined in terms of postcolonial "fight".

The war in Eastern Congo and Western "complicities" (political, economic and intellectual) are at the heart of all the opposition's discourses. This leads to a huge criticism of the Western democracies and to a political anti-imperialist consciousness, anti-imperialist, that situates the Congolese case in more global stakes. 
The gap between Western democratic or humanist principles and its implementation in the third-world constitutes the centre of this three-fold postcolonial critique. First, there is the idea of an international conspiracy. Secondly, there is the idea that colonization blurred ethnicities, which is said to have led to the Rwandese aggression as well as the state of impunity maintained by the international community. Finally, there exists the idea that Belgian expertise on Congo which is internationally recognized, is marred by a colonial ideology that is found in the media and in the academic world.

Because the idea of an international conspiracy is closely linked to the mineral wealth of Congo, this international conspiracy's theme systematically leads to the colonization. Despite various levels of knowledge among our informants, some episodes are undeniably part of the collective memory like the "hand cut" practice under Leopold II, the European greed and the French preemptive right on Congo at the late XIXe century for example. The various forms of interferences in the Congolese politics by European and American governments is also systematically mentioned like Lumumba and Kabila's assassination or the support to Mobutu's dictatorship.

In this respect, the United Nations is in a paradigmatic manner the expression of the international conspiracy. The UN's refusal to leave DRC, despite Congolese government's requests, would reaffirm the evidence of a fundamental ambiguity. The UN is criticized for the lack of results (the war still goes on since 1998) but also for its ideology that is said to be contrary to objectives of peace. The peacekeeping soldiers are for example accused - like the Congolese soldiers- of incompetence and of being involved in Lumumba assassination in 1960-61 as well as in the large-scale rapes and destruction in Eastern Congo since the late 1990'.

While UN reports have progressively established the Rwandese involvement in this war (Reyntjens 2004; DRC mapping report, ${ }^{21}$ etc.), UN forms of actions have not really changed. The most recent example is probably the UN decision not to intervene in November 2012 while the M23 (a Rwandese rebellion movement) took and sacked once again the city of Goma.

The ethnic blurring on which the Rwandese impunity is based for about fifteen years is linked to colonial migrations policies, the "françafrique"'s politics and more generally to the international community's involvement in the

21) DRC: Mapping human rights violations 1993-2003, United Nations: Rapport du Projet Mapping concernant les violations les plus graves des droits de l'homme et du droit international humanitaire commises entre mars 1993 et juin 2003 sur le territoire de la République démocratique du Congo, Août 2010, Nations Unies. 
region. Since the Rwandese genocide is regarded as the starting point of the socalled "Congolese war", we briefly recall the context that is perfectly known by the diaspora and explains this ethnic blurring. In 1994, the French "turquoise operation" under UN presence compelled the Zairian government to displace 1.5 million Rwandese people (former Rwandese army and the genocidal militias (Interahamwe) were among them). Between June and July 1994, these people settled on the Rwandese-Congolese border (in camps in Northern and Southern Kivu). The current war that started in 1998 partly takes its justification from the Rwandese chasing up of "genocidaires" who took refuge in Congo. In addition to these refugees, several waves of Rwandese migrations had already occurred during the colonization to respond to Belgium's need of labor for its "exploitation's colony" (namely Congo). Thus, when international organizations during the Transition (after LD Kabila assassination, 2001) called to recognize the "right of the Tutsi minority" in a ethnic pluralism (350 groups) country, the overall diaspora denounced the imposture. Congolese activists criticized the so-called self-defense arguments of Rwanda and Uganda and denounced the risk of "balkanizing" Congo. Various Congolese websites denounced the fact that "banyamulenge" (Congolese with a Tutsi- Rwandan origin who settled in Eastern Congo (Kivu), a term which means in Kinyarwanda, the national language in Rwanda, "people from the Hills") is not a Congolese ethnic group. The diaspora (far well beyond the politically active diaspora) then criticized the spectacular political, economic, and military insertion of Rwandese people in DRC. ${ }^{22}$ On Websites, one could see how the idea of "Congolese xenophobia" against Rwandese people was denounced as well as the Belgian government's responsibility in this ethnic conflict.

"Belgian people know very well that there are no Tutsi in Congo", explains a militant from Apareco after consulting the archives of the Tervuren museum on the ethnic composition of Congo before colonization. He goes on: "It's Belgium that wrote up the constitution; it's Belgium that covers everything up" (Interview March 2009).

Even though the term banoko (uncles in Lingala) is not used anymore among Congolese circles to describe Belgian-Congolese relationships, the feeling that Belgium should feel morally guilty because of the colonization and that Belgium is indebted to DRC remains. Many people in the diaspora believe that Congolese living in Belgium should receive special treatment and that the so-called Belgian expertise should cover more DRC point of view. Even outside of politicized groups, it is not rare to hear that "Congo gave everything to

22) In this regard, see Willame (1997). 
Belgium, but Belgian people don't like Congolese". This point of view is further fueled because of the resentment caused by the low social status enjoyed by this minority in Belgium. Thus, in January 2012, when the violence of the demonstration began to decrease, more "pedagogical" slogans aimed at people in the street or Belgian or European institutions emerged, such as "Uranium for the Congolese! Diamonds for the Congolese! Gold, Uranium for the Congolese!... French fries for Belgians, mussels, chocolate for Belgians!, etc.".

Beyond the resentment caused by the war, the demonstrators and many members of the diaspora consider the international recognition of Belgium's expertise on Congo as problematic since medias, academics and politicians are not always objective because of conflict of interests.

Some journalists are clearly portrayed as "anti-Congo" and are regularly criticized in the public space and on the Internet. Others are perceived as more ambivalent according to where they write (in their editorials, international media, or in an academic or militant framework). Depending on their position, the diaspora quote them or contest them.

In addition to that, critics that denounce an (imperialist) ideology also point out the superficiality and errors of interpretation that are found in mainstream analyses of DRC politics. For example, the prevalence of Balubas, an ethnic group from Kasai, to predict Tshisekedi's election. With such an erroneous analysis, this journalist demonstrates that he is neither aware of the pluralism of ethnicities in this region nor of the non homogeneity of this very group characterized by considerable internal strives.

For this other informant: "I remember when we used to live in Congo under Mobutu, we didn't have access to foreign books. We used to hear about such or such book, we thought there must exist real revelations, but when we came here and read these books.... Honestly! It's really the knowledge of Congolese in the street" (Journalist, former activist of the website Stand up Congolese).

It came out from our interviews with Belgian journalists that they do not give much credit to the diaspora's political actions (even if some admitted that they "learned a lot" by frequently reading some websites). They often criticize the lack of organization, the changes of coalitions, and personal ambitions. Nevertheless, it is interesting to note that after the demonstrations and the violent questioning of the Belgian media's credibility, we saw explicit forms of justification, in writing (blogs and even books) or in conferences (in community spaces or universities) from some Belgian journalists. Belgo-Congolese politicians (denounced as useless by demonstrators) also justified themselves through social media in explaining how their position and the complexity 
of Belgian politics do not allow them to be active in Belgian foreign policy towards Congo.

Like journalists, politicians may also be criticized by the activists of partiality in their Congolese analysis because of personal or familial history (having or having had economic interested in DRC). The harsh criticisms addressed to Louis Michel (member of the French speaking liberal party, Minister of Foreign affairs from 1999 to 2004 and European Development Commission) who played an active role in resolving the "Congolese crisis" (after L.-D. Kabila's assassination) are emblematic. Attacked by so many critics, the politician sued the UDPS representative (20/07/06) for abusive comments and defamation (insults such as "sadist slave driver", "voracious predator", "pyromaniac", "plunderer of national wealth", "enemy of the Congolese people"). ${ }^{23}$ In the diaspora the relationship between Louis Michel and the Belgian businessman George Forrest is perceived as strengthening the ambiguities concerning the Belgian politics as regards of the financial and mining empire he built in Katanga, (post)colonial bastion par excellence (Rubbers 2009).

In this regards, it is also in domestic and migratory politics that the double discourse associated with colonial rationale is denounced. Belgium is strongly perceived as "pro-Rwanda" in its foreign policy and in domestic policy regarding postcolonial migrants. The diaspora cites the opening of the Belgian border to welcome genocide survivors in the aftermath of the Rwandan genocide while the Congolese war did not bring about softer Belgian migratory policies. The diaspora stresses the double standard the "international community" applies with regard to Congo. Congo was asked to carry out a flexible migratory policy vis-a-vis Rwandese refugees or "Tutsi-Congolese" while Belgian migratory policies towards Congolese are very stringent. This issue refers to the whole Belgian colonial space (Congo, Burundi, Rwanda) and to the link between the different material investment of the Belgian in colony and the colonial imaginary related to each colonial territory.

Economic interest and (Belgian) imaginary are strongly linked to the ethnic blurring's question that emerges in diaspora discourses as the main feature of the international conspiracy. While $\mathrm{NGOs}^{24}$ speak of 6 million deaths

23) Justice considered that the statements were "apparently calomnious and damaged the reputation and honour of Louis Michel". Justice reminded that "even if freedom of expression must be privileged, it is not unlimited." cf. Vandendries Jean, "Injures interdites contre Louis Michel" Le Soir, September 13 th 2006, p. 16.

24) See 2007 d'International Rescue Committee report that already talks of 5.4 million deaths and 45,000 deaths each month, consulted on July 12 th 2012. 
(some Congolese groups within the opposition calculate 8 to 10 million), some scholars have estimated at 183,000 the number of death as a consequence of the war. ${ }^{25}$ The fact they are Belgian strongly confirms in diaspora's eyes the general minimization of war's horrors, and the fact that war is also an information warfare (Mayoyo 2006). The diaspora expresses abundantly acute criticisms about the American and French injunction to respectively "turn the page on the past" (Hilary Clinton 2009), ${ }^{26}$ to "share wealth with their neighbors" (Nicolas Sarkozy, 2009) ${ }^{27}$ and to the Belgian call to declare the illegitimacy of Chinese partnerships in DRC (Karel de Gucht 2009). ${ }^{28}$

\section{Conclusion}

The postcolonial stakes of Congolese political space we examined in this paper refer to various levels of analysis. As we have shown, the history of the political landscape (since 1960) shows the transformation of transnational practices that was facilitated by the arrival of new technologies on the one hand and by the intensification of mobility on the other hand. Migratory waves and movements have not only modified the political cartography of the diaspora but also the modes of political participation. The most visible opposition in the for-

25) Cf. Lambert André and Lohle-Tart Louis "La surmortalité au Congo (RDC) durant les troubles de 1998-2004- une estimation des décès en surnombre, scientifiquement fondée à partir des méthodes de la démographie", October 2008.

26) While visiting Congo and Rwanda, Hillary Clinton, American Secretary of State, talked to the Congolese in Goma in these terms (that were diffused by all Congolese media) (6/08/2009): "We want to work with people committed to a better future and not with people that refer themselves to the past".

27) Nicolas Sarkozy addressing its wishes to the French diplomatic body. cf. "La France prépare une initiative de paix pour l'est de la République démocratique du Congo", le Monde, January 18th 2009 .

28) In all the Congolese press, one may read that the Dutch-speaking Belgian minister Karel de Gucht had expressed the will of his country to have a right of regard on the contract signed between Kinshasa and Pekin that was worth more than 15 billion dollars because Belgium gives 200 million euro every year to Congo as development cooperation aid. In reaction, DRC closed the Congolese consulate in Antwerp and the Belgian consulate in Lubumbashi and Bukavu and recalled for consultation the ambassador in Brussels. It was only in January 2009 that it was decided to reopen consulates for the following August. Other sources specially Dutch-speaking mentioned that the diplomatic incident happened after Karel De Gucht accused the Congolese elites of corruption. See eg: http://www.rnw.nl/africa/article/belgian-king-visit-democraticrepublic-congo. But there may of course be other reasons. 
mer metropole happened under Mobutu and Kabila's son and presented some kind of continuity despite the changing political context. However, the $2000 \mathrm{~s}$ have seen a significant reorganization of the transnational political space into a much more explicit, not to say virulent, opposition to Belgian and Congolese state monopolies. The violent attacks on Congolese personalities and elites by the Combatants (a pressure group specific to the diaspora) and the harsh criticism towards Belgian and Western experts illustrate well this trend. Blogs and social networks have a subversive reach vis-à-vis mainstream media but their drawback is that they present risks of disinformation within the diaspora. The predominance of "orality" (putting rumors on paper) on the web (mainly social networks) may reflect certain modes of political expression and processes of differentiation as well as the low education level of some activists. These forms of activism cannot nevertheless be dismissed as being non-professional since they reveal insightful information on Congolese politics and a plurality of actors.

To what extend does the diaspora create social dynamics or on the contrary reinforce existing dynamics is hard to tell. The idea of an international conspiracy is for example widespread in DRC. ${ }^{29}$ Nevertheless, there is a specific opposition activism in Europe. The fact that Congolese politicians include Europe in their electoral campaign despite the fact the diaspora cannot vote is significant of the diaspora's incidence, at least in what concerns DRC elites' level. Finally, the link between federative dynamics within a fragmented and plural landscape and the different interpretations of the history of anti-colonial and anti-imperialist struggles is definitively the major expression of the postcolonial stakes we aimed to explore. This double dynamic is particularly visible in Belgium that used to be a territorial extension of Congo-Zaïre in the imaginary and the mobilities of Congolese elites. In this regard, we can say that Congolese presence in Belgium defines a peculiar political landscape since people's spatial mobility is closely associated with their displacement in the political space at least until the end of the 199o's. The connection Kinshasa - Brussels inherited from colonization is still intense despite the fact that Belgium does not "produce" political Congolese elites any longer. The low social status of Congolese in Belgium may feed the opposition's virulence and should further be compared with other countries. It would also be helpful to investigate if

29) Maria Eriksson Baaz - Willing reform? Navigating external defense reform initiatives in the Congolese Armed Forces. Paper presented at the 2012 African Studies Associations of UK, Leeds, September 6th 2012. 
there is a Congolese and diasporic expertise for the Belgian establishement; and if yes, to see if it is translated into an institutional framework and recognized as such, or if it remains circumstantial and ad hoc.

53 years after Independence, the dispute still remains and are numerous, among them the issue of political expertise about Congo. It is maybe because it is not common to hear Belgian experts on Congo with a Congolese origin that postcolonial era is eventually still locked in the ghosts of its colonial past.

\section{References}

Al-Ali, N., Black, R. and Koser, K. 2001. Refugees and transnationalism: The experience of Bosnians and Eritreans in Europe, Journal of Ethnic and Migration Studies, 27 (4): 615-634.

Asch, L., Glick Schiller, N. and Blanc-Szanton, C. 1994. Nations Unbound: Transnational Projects, Postcolonial Predicaments and Deterritorialized Nation-states. New York: Gordon \& Breach.

Bancel, N., Riot, T. 2009. Génocide ou "guerre tribale": les mémoires controversées du génocide rwandais, Hermès CNRS, Communication/Cognition/Politique, $\mathrm{n}^{\mathrm{o}} 5^{2}$, 1e semestre 2009, p. 139-148.

Bancel N., F. Bergnault, P. Blanchard, A. Boubeker, A. Mbembe and F. Vergès (eds.) 2010. Ruptures postcoloniales, Les nouveaux visages de la société française. Paris: La Découverte.

Bauböck, R. 2003. Towards a political theory of migrant transnationalism, International migration review, 37 (3): 700-723.

Bayart, J.-F. 2010. Les études postcoloniales. Un carnaval académique. Karthala, coll. “Disputatio”, 2010, 126 p.

Bayart, J.-F, Mbembe, A. and Toulabor C. 1992. Le politique par le bas en Afrique noire: contributions à une problématique de la démocratie. Paris: Karthala.

- 1993 (first French edition, 1989). The State in Africa: The Politics of the Belly London, Longman.

Bernal, V. 2006. Diaspora, cyberspace and political imagination: the Eritrean diaspora online, Global Networks, 6(2):168.

Chakrabarty, D. 2007 (2000). Provincializing Europe- Postcolonial Thought and Historical Difference. Princeton: Princeton University Press.

Cooper, F. and Stoler, A. L. 2002. Decolonizing Situations: The Rise, Fall, and Rise of Colonial Studies, 1951-2001. French Politics, Culture, and Society 20(2):47-76.

Demart, S. 2010. les territoires de la délivrance. Mises en perspective historique et plurilocalisée du Réveil congolais (Bruxelles, Kinshasa, Paris, Toulouse), thèse de Doctorat, Université Toulouse-le-Mirail et Université catholique de Louvain-la-Neuve, Toulouse.

_. 2013a. Histoire orale à Matonge (Bruxelles): un miroir postcolonial", Revue Européenne des Migrations Internationales, $\mathrm{n}^{\mathrm{o}}$ varia, forthcoming.

- 2013b. La participation politique des chrétiens d'origine congolaise (RDC) à Bruxelles in Présences subsahariennes en Belgique: un état des lieux", (eds.) Jacinthe Mazzocchetti, Academia-H, Louvain-la-Neuve.

- 2013c. Riots in Matonge and ... the indifference of public authority?, Brussels Studies, Number 68, July 1st 2013 . 
De Villers, G. \& Willame, J.-C. 1999. République démocratique du Congoếpchronique politique d'un entre-deux-guerres, octobre 1996-juillet 1998, Cahiers africains du Cédaf, nº 35-38, ed. L'Harmattan.

De Witte, L. 2000. L'assassinat de Lumumba. Paris: Karthala.

Etambala, Z. 1993. In het land van de Banoko: de geschiedenis van de Kongolese/Zaïrese aanwezigheid in België van 1885 tot heden, (Steunpunt Migranten - Cahiers nº 7 ), Leuven.

Garbin, D. and Godin, M. 2013. 'Saving the Congo': transnational social fields and politics of home in the Congolese diaspora, in African and Black diaspora: An International Journal. Special issue on Diaspora and Migration: Rethinking African Development in the 21st Century, Forthcoming.

Gilroy, P. 2005. Postcolonial Melancholia, New York: Columbia University Press.

Grillo, R. \& Mazzucato, V. 2007. Africa-Europe: a double engagement, Journal of ethnic and migration studies, 34 (2): 175-198.

Guarnizo, L., Portes, A. and Haller, W. 2003. Assimilation and transnationalism: determinants of transnational political action among contemporary migrants, The American Journal of Sociology, 108(6):1211-1248.

Gueye, A. 2011. The Colony Within the Métropole: The Racial Diversity of Contemporary France and the Insertion of the Colonial Past in the National Narrative, Canadian Journal of African Studies 45(1): 1-16.

Hunt, N. R. 1999 A Colonial Lexicon: Of Birth Ritual, Medicalization, and Mobility in the Congo. Durham, NC: Duke University Press.

Kennes, E. N'Ge, M., 2003. Les multinationales et la mise en concurrence des salaries. Paris, L'Harmattan (Cahiers Africains).

Kivisto, P. 2001. Theorizing transnational immigration: a critical review of current efforts, Ethnic and Racial Studies, 24(4): 549-77.

Lebovics, H. 2004. Bringing the Empire Back Home: France in the Global Age. Durham \& London, Duke University Press.

Martiniello, M. \& Lafleur, J.-M. 2008. Towards a transatlantic dialogue in the study of immigrant political transnationalism, Ethnic and Racial Studies, 31 (4): 645-663.

Mayoyo, B. T. 1995. Migration sud/nord levier ou obstacle les zairois en Belgique. Vol. 4, L'Harmattan: Cahiers Africains 13.

- 2006. La deuxième guerre occidentale contre le Congo: offensive des médias et dessous des cartes. Paris: l'Harmattan.

Mbembe, A. 2001 (2000). On the Postcolony, Berkeley, CA: University of California Press.

Mügge, L. 2010. Beyond Dutch borders: transnational politics among colonial migrants, guest workers and the second generation (IMISCOE Research), Amsterdam, Amsterdam University Press.

Ndaywel, I. 1998. Histoire générale du Congo. De l'héritage ancien à la République Démocratique. Paris/ Bruxelles, De Boeck \& Larcier.

Omasomba Tshonda, J. 2004. Lumumba, drame sans fin et deuil inachevé de la colonisation, Cahiers d'études africaines 1-2: 173-174.

Østergaard-Nielsen, E. 2003. Transnational Politics: Turks and Kurds in Germany, London, Routledge.

Reyntjens, F. 2004. Rwanda, ten years on: From genocide to dictatorship, African Affairs, 103 (411), $177-210$.

Rubbers, B. 2009. Faire fortune en Afrique: Anthropologie des derniers colons du Katanga. Paris: Karthala. 
Saïd, E. 1978. Orientalism. Pantheon books. Michigan: University of Michigan.

Schoonvaere Quentin, (2010) Etude de la migration congolaise et de son impact sur la présence congolaise en Belgique: Analyse des principales données démographiques, Ucl et centre pour l'Egalité des chances.

Schütz, A. 1987. Le chercheur et le quotidien. Phénoménologie des sciences sociales, Paris, Méridiens Klincksieck.

Stoler, A. L. 2008. Imperial Debris: Reflections on Ruins and Ruination. Cultural Anthropology, 23(2):191-219.

Tshimanga, C., Gondola, D., Bloom, J. 2009. Frenchness and the African Diaspora: Identity and Uprising in Contemporary France, Bloomington, Indianapolis: Indiana University Press.

Tshitungu, A., 2011. Visages de Paul Panda Farnana Nationaliste Panafricaniste Intellectuel, Paris: L'Harmattan.

Turner, S. 2008. The Waxing and Waning of the Political Field in Burundi and it Diaspora in The Transnational Political Participation of Immigrants A Transatlantic Perspective (Lafleur and Martiniello, eds.) Ethnic and Racial Studies 31(4): 742-765.

Vertovec, S. 1999. Three meanings of “diaspora”, exemplified by South Asian religions,' Diaspora 6(3): 277-300.

Vertovec, S., 2004. Cheap calls: the social glue of migrant transnationalism, Global Networks, 4(2): 219-24.

Willame, J.-C. 1997. Banyarwanda et Banyamulenge: Violences ethniques et gestion de l'identité au Kivu, Cahiers africains- CEDAF n ${ }^{\circ}$ 25, Paris, L'Harmattan.

Wynants, P. 2010. Un printemps pour les "petits partis"? (4è partie) in la Revue Nouvelles, 66 (2):78-8. 